Original Research Paper

\title{
Diet and Behavior of Macaca fascicularis for Ecotourism Contributing on Pengsong Area
}

\author{
M. Yamin ${ }^{1 *}$, Dadi Setiadi ${ }^{1}$, Khairuddin ${ }^{1}$ \\ ${ }^{1}$ Program Studi Pendidikan Biologi, Fakultas Keguruan dan Ilmu Pendidikan, Universitas Mataram, Indonesia
}

\author{
Article History \\ Received : October $14^{\text {th }}, 2020$ \\ Revised : October $22^{\text {th }}, 2020$ \\ Accepted : December $28^{\text {th }}, 2020$ \\ Published : February 02 $2^{\text {th }}, 2021$ \\ *Corresponding Author: \\ M. Yamin, \\ Program Studi Pendidikan Biologi, \\ Fakultas Keguruan dan Ilmu \\ Pendidikan, Universitas Mataram, \\ Indonesia; \\ email: \\ muhammadyamin.fkip@gmail.com
}

\section{Pendahuluan}

Areal Wisata Gunung Pengsong terletak di bagian Selatan Kota Mataram, berjarak sekitar lima kilometer dari pusat kota, memiliki pemandangan yang indah, dekat pantai, dikelilingi daerah pertanian dan dihuni berbagai jenis flora dan fauna diantaranya Macaca fascicularis. Pengsong merupakan salah satu areal ekowisata pegunungan dengan pemandangan alam yang lengkap dan keragaman hayati yang menarikwisatawan, diantaranya adalah keberadaan populasi Macaca fascicularis. Seluruh keragaman hayati tersebut merupakan modal yang perlu dimanfaatkan secara optimal untuk pembangunan. Macaca fascicularis sangat potensial untuk pengembangan obyek wisata khususnya ekowisata (Purnomo et al., 2013; Haris et al., 2017; Yuniarti et al., 2018; Aurelia et al., 2020). Selain itu, juga penting dalam kehidupan, untuk menunjang kelangsungan seluruh kehidupan maupun untuk memenuhi kebutuhan manusia seperti kebutuhan ekonomi, ekologi, sosial-budaya, estetika, dan ilmu pengetahuan (Mangunjaya, 2015; Supriatna, 2018).

Pemanfaatan Macaca fascicularis sebagai obyek penarik wisatawan belum di kelola dan dimafaatkan maskimal (Daniar, 2016; Bambang \& Roedjinandari, 2017). Sedangkan, Dalam upaya menggali potensi daerah untuk meningkatkan pendapatan asli daerah khususnya daerah Nusa Tenggara Barat (NTB). Penelitian terkait pengembangan obyek wisata 
telah banyak dilakukan, khususnya di NTB diantaranya yang menjadi prioritas adalah menggali dan mengembangkan daerah dengan keragaman hayatinya untuk dijadikan sebagai daerah tujuan wisata, baik untuk wisatawan nusantara/local maupun mancanegara/Internasional.

Kawasan Gunung Pengsong, memiliki beberapa tipe habitat, seperti hutan, semak, padang rumput, tegalan/kebun dan persawahan. Kawasan tersebut ditempati berbagai jenis satwa, namun keberadaan jenis, populasi, makanan, perilakudan kondisi habitat satwa khususnya Macaca fascicularis belum pernah dilaporkan. Salah satu potensi fisik yang menarik wisatawan berkunjung ke suatu obyek wisata adalah kekayaan dan kekhasan keanekaragaman hayati yang dimiliki oleh obyek wisata tersebut (Maryadi, 1993). Wisata yang saat ini sangat populer di dunia adalah wisata alam (nature tourism) (Awalia, 2017; Syah, 2017). Untuk meningkatkan jumlah kunjungan wisata perlu meningkatkan daya tarik obyek misalnya dengan penataan lingkungan tempat tujuan wisata (Mardalis\& Wijaya, 2016; Utama, 2017). Penataan lingkungan destinasi wisata yang baik dapat dilakukan bila memiliki data dan informasi yang lengkap mengenai sumber daya yang dimilikinya. Oleh karena itu, penelitian mengenai segala aspek sumber daya di kawasan wisata Gunung Pengsong khususnya mengenai habitat dan perilaku Macaca fascicularis menjadi sangat penting dilakukan.

\section{Bahan dan Metode}

Penelitian ini diarahkan untuk mengetahui karakteristik habitat dan perilaku Macaca fascicularis. Aspek yang diteliti meliputi jenis, komposisi dan struktur vegetasi, makanan, aktivitas harian, perilaku sosial, perilaku kawin dan perbandingan jenis kelamin.

\section{Metode Penelitian}

Data habitat yang diambil yaitu komponen biotik dan abiotik. Komponen biotik meliputi vegetasi semua tingkat. Pengambilan data menggunakan metode kuadrat berukuran $50 \mathrm{~m} \mathrm{x}$ $50 \mathrm{~m}$. Setiap plot dibagi menjadi 5 petak contoh ukuran $10 \mathrm{~m}$ x $50 \mathrm{~m}$ (Winarti, 2011). Semua tumbuhan yang terdapat di dalam setiap petak contoh dicatat nama spesies, jumlah individu, tinggi tajuk, diameter batang, luas kanopi dan penggunaannya oleh Macaca fascicularis. Selain data komponen biotik tersebut di atas, diambil pula data abiotik yang meliputi cuaca, suhu, kelembaban, kelerangan, ketinggian tempat dari permukaan laut, sumber pakan, minum, tempat bermain, istirahat, tidur, berlindung, berbiak, dan pengganggu populasi Macaca fascicularis.

Data Perilaku Macaca fascicularis. Pengambilan data dilapangan dengan menggunakan metode broad survey dan line transect. Dilakukan selama waktu makan pagi, siang dan sore hari. Data perilaku Macaca fascicularis yang dipelajari meliputi aktivitas harian, waktu makan, bermain, istirahat, berbiak, struktur populasi, pengganggu populasi, pola sosial dan daerah jelajah

\section{Analisis Data Penelitian}

Análisis Data hábitat dari hasil studi yang diperoleh kemudian dianalisis secara kuantitatif terhadap penggunaan sumber daya, yang meliputi: uji korelasi dengan Uji Chi-kuadrat (X2) (Santosa et al., 2012), Indeks Nilai Penting (INP) (Febriyanti \& Kiroh, 2019), Indeks Shannon-Wiener untuk menentukan keanekaragaman jenis (H') (Krebs, 1978), Indeks Margaleff untuk menentukan kelimpahan jenis (E) (Magurran, 1988), Indeks Jaccard untuk menentukan kesamaan jenis (IS) dan Pola sebaran populasi (Odum, 1971).Untuk mengenal jenis tumbuhan digunakan Buku Pengenalan Tumbuhan dari Graf (1992). Selanjutnya, Data Perilaku yang diperoleh dianalisis secara kualitatif. Analisis kualitatif dilakukan dengan cara mendeskripsikan semua aktivitas Macaca fascicularis, struktur populasi, sumber pakan, predator, pengganggu populasi dan pola dalam menggunakan sumber daya

\section{Hasil dan Pembahasan}

\section{Habitat Macaca fascicularis di Kawasan Gunung Pengsong}

Habitat adalah tempat organismo biasanya ditemukan meliputi tanah, air, iklim, dan komponen biotik yang merupakan satu kesatuan yang digunakan sebagai tempat hidup dan berkembang biak (Alikodra, 1990). Habitat merupakan faktor paling penting yang berpengaruh langsung terhadap populasi satwa liar (Bismark, 1984). Macaca fascicularis memiliki kemampuan beradaptasi dengan berbagai kondisi lingkungan berbeda. Pada mulanya kehidupan primata ini adalah arboreal, mereka bertempat tinggal terutama di pohon-pohon dan hanya beberapa saja yang hidup di darat. Habitat asli Macaca fascicularis 
adalah rawa-rawa bakau, tetapi ditemui juga pada hutan primer dan sekunder pada ketinggian 2000 meter di atas permukaan laut, selain itu juga terdapat pada perbatasan areal hutan dan pertanian (Mukhtar, 1982). Jenis ini dianggap sebagai binatang pengganggu karena sering merusak tanaman perkebunan, jagung, ketela, pepaya dan pisang (Sugiharto, 1992). Menurut Linburg (1980), Macaca fascicularis banyak ditemui di hábitat terganggu khususnya daerah ripairan (tepisungai, tepidanau, dan sepanjang pantai dan hutan sekunder areal perladangan.

Gunung Pengsong merupakan bukit berbatu dengan ketinggian \pm 200 meter dari permukaan laut. Terletak \pm 10 kilometer arah
Barat daya Bandara Salaparang, di puncaknya terdapat Pura yang konon merupakan Pura pertama dan tertua di Pulau Lombok. Pura ini beridiri sekitarTahun 1514. Oleh sebab itu, sejak tahun 1996 Gunung Pengsong ditetapkan sebagai kawasan Cagar Budaya dan obyek wisata alam seluas \pm 11 Hektar. Area ini merupakan hábitat berbagai jenis flora dan satwa diantaranya potencial sebagai obyek wisata, misalny asatwa Macaca fascuculari. Gunung Pengsong dikelilingi oleh daerah pemukiman dan pertanian berupa sawah dan perkebunan. Berikut disajikan gambaran habitat Macaca fascucularis di areal wisata Gunung Pengsong, khusus komponen vegetasinya pada Bulan Agustus Tahun 2020 seperti pada Tabel 1.

Tabel1. Daftar Spesies, Komposisi, Tinggi Tajuk dan Pemanfaatannya Vegetasi oleh Macaca fascicularis di Gunung Pengsong Bulan Agustus Tahun 2020.

\begin{tabular}{|c|c|c|c|c|c|c|c|c|c|c|}
\hline \multirow[t]{2}{*}{ No } & \multicolumn{2}{|c|}{ Nama Tumbuhan } & \multicolumn{2}{|c|}{$\begin{array}{l}\text { Jumlah } \\
\text { Stasiun }\end{array}$} & \multirow[t]{2}{*}{$\sum$} & \multirow[t]{2}{*}{ Tajuk } & \multicolumn{4}{|c|}{$\begin{array}{c}\text { Bagian yang } \\
\text { Dimakan }\end{array}$} \\
\hline & Lokal & Latin & I & II & & & $\mathrm{D}$ & $\mathrm{Bg}$ & $\mathrm{Bh}$ & $\mathrm{Sb}$ \\
\hline 1. & Ara & Ficus carica & 5 & 9 & 14 & 7 & & & $\sqrt{ }$ & \\
\hline 2. & Aren & Arenga pinnata & 1 & 0 & 1 & 7 & & & & \\
\hline 3. & Asam & Tamarindus indica & 3 & 11 & 14 & 25 & & & $\sqrt{ }$ & \\
\hline 4. & Awar awar & Ficus septica & 2 & 9 & 11 & 20 & & & $\sqrt{ }$ & \\
\hline 5. & Bajur & Schoutenia ovata & 0 & 39 & 39 & 35 & & & & \\
\hline 6. & Banten & Aphanamixis grandiflora & 2 & 0 & 2 & 15 & & & & \\
\hline 7. & Bila/maja & Cryptorenoria paniculata & 0 & 5 & 5 & 10 & & & $\sqrt{ }$ & \\
\hline 8. & Beringin & Ficus superba & 5 & 7 & 12 & 40 & & & $\sqrt{ }$ & \\
\hline 9. & Kelor & Moringa oleifera & 3 & 0 & 3 & 7 & & & & \\
\hline 10. & Barora & Klemhovia hespita & 0 & 27 & 27 & 12 & & & & \\
\hline 11. & Bengkal & Nauclea speciosa & 0 & 5 & 5 & 15 & & & & \\
\hline 12. & Bugenvil & Bougainvillea spectabilis & 2 & 0 & 2 & 10 & & & & \\
\hline 13. & Boro & Sterculia oblongata & 2 & 0 & 2 & 5 & & $\sqrt{ }$ & $\sqrt{ }$ & \\
\hline 14. & Bungur & Lagerstroemia speciosa & 0 & 31 & 31 & 25 & & & & \\
\hline 15. & Busir & Acacia abyssnu & 3 & 50 & 53 & 15 & & & & \\
\hline 16. & Bruno & Antidesmo bruno & 0 & 4 & 4 & 9 & & & & \\
\hline 17. & Bidara & Merremia sp. & 3 & 17 & 20 & 10 & & & $\sqrt{ }$ & \\
\hline 18. & Cemara & Casuarina cunninghamiana & 2 & 0 & 2 & 35 & & & $\sqrt{ }$ & \\
\hline 19. & Ceruring & Lansium domesticum & 2 & 0 & 2 & 10 & & & $\sqrt{ }$ & \\
\hline 20. & Dope & Bauhinia sp. & 3 & 19 & 22 & 15 & & & & \\
\hline 21. & Duren & Durio zibethinus & 1 & 0 & 1 & 5 & & & $\sqrt{ }$ & \\
\hline 22. & Jambu air & Eugenia aquea & 2 & 0 & 2 & 30 & & & $\sqrt{ }$ & \\
\hline 23. & Jati putih & Gmelina arborea Roxb & 0 & 5 & 5 & 20 & & & & \\
\hline 24. & Jati & Tectona grandis & 2 & 0 & 2 & 20 & & & & \\
\hline 25. & Johar & Cassia siamea Link & 0 & 9 & 9 & 20 & & $\sqrt{ }$ & & \\
\hline 26. & Juwet & Syzygium cumini & 2 & 0 & 2 & 25 & & & $\sqrt{ }$ & \\
\hline 27. & Kamboja & Plumiera acuminata & 1 & 0 & 1 & 5 & & & & \\
\hline 28. & Karsen & Muntingia calabura & 2 & 0 & 2 & 7 & & & $\sqrt{ }$ & \\
\hline 29. & Katimis & Protium javanicum & 7 & 39 & 46 & 25 & $\sqrt{ }$ & & $\sqrt{ }$ & \\
\hline 30. & Kasaming & Schleichera oleosa & 7 & 23 & 30 & 20 & & & $\sqrt{ }$ & \\
\hline 31. & Kanangas & Ximenia sp. & 1 & 7 & 8 & 7 & & & $\sqrt{ }$ & \\
\hline 32. & Kayu batu & Alstonia spectabilis & 0 & 13 & 13 & 12 & & & & \\
\hline 33. & Katapang & Terminalia catapa & 2 & 0 & 2 & 7 & & $\sqrt{ }$ & & \\
\hline
\end{tabular}




\begin{tabular}{|l|l|l|c|c|c|c|c|c|c|c|}
\hline 34. & Kelapa & Cocos nicifera & 5 & 0 & 5 & 13 & & & & \\
\hline 35. & Lamtoro & Leucaena glauca & 7 & 35 & 42 & 20 & & & $\sqrt{ }$ & \\
\hline 36. & Lanung & Halian thementasum & 0 & 10 & 10 & 12 & & & & \\
\hline 37. & Lita & Alstonia scholaris & 0 & 3 & 3 & 20 & & & & \\
\hline 38. & Malaka & Phyllantus emblica & 0 & 15 & 15 & 13 & & & $\sqrt{ }$ & \\
\hline 39. & Mangga & Mangifera indica & 6 & 0 & 6 & 25 & & & $\sqrt{ }$ & \\
\hline 40. & Mahoni & Switenia macrophylla & 9 & 0 & 9 & 15 & & & & \\
\hline 41. & Nangka & Artocarpus integra & 1 & 0 & 1 & 10 & & & $\sqrt{ }$ & \\
\hline 42. & Peko & Cynodon dactylon & 0 & 9 & 9 & 7 & & & & \\
\hline 43. & Pelas & Saripellus asper & 7 & 21 & 28 & 10 & & & $\sqrt{ }$ & \\
\hline 44. & Renung & Ceiba pentandra & 1 & 0 & 1 & 15 & & & $\sqrt{ }$ & \\
\hline 45. & Sareong & Albizzia lebbek & 2 & 11 & 13 & 20 & & & & \\
\hline 46. & Waru & Thespesia populnea & 1 & 0 & 1 & 10 & & & & \\
\hline 47. & Sirsak & Annona muricata & 2 & 0 & 2 & 5 & & & $\sqrt{ }$ & \\
\hline 48. & Suran & Toona sureni & 0 & 12 & 12 & 15 & & & & \\
\hline 49. & Tampoak & Eugenia sp. & 1 & 3 & 4 & 25 & & & $\sqrt{ }$ & \\
\hline Jumlah individu Tumbuhan & & 35 & 29 & & & & & & \\
\hline Jumlah spesies & & & & & & \\
\hline
\end{tabular}

Keterangan: $\mathrm{I}=$ Pinggir Hutan Areal Pura di Pelataran, $\mathrm{II}=$ Dalam Hutan

$\mathrm{D}=$ Daun, $\mathrm{Bg}=$ Bunga, $\mathrm{Bh}=\mathrm{Buah}, \mathrm{SB}=$ Semua bagian

Tabel 2. Hasil Analisis Indeks Keanekaragaman Jenis Vegetasi di pinggir dan dalam hutan Areal Wisata Gunung Pengsong Bulan Agustus Tahun 2020

Index

Shannon H' Log Base 10.

Shannon Hmax Log Base 10.

Sample 1

1.446

1.544

Shannon J'

0.937

Sample 2

Sample 3

1.455

1.69

1.447

0.919

0.861

Dari penelitian ini tercatat 49 jenis vegetasi pohon yang ditemukan pada dua stasiun pengamatan yaitu di areal pinggir hutan pada pelataran candi dan areal dalam hutan. Jumlah jenis, Indeks Keanekaragaman, Indeks Nilai Penting, dan kerapatan pohon di setiap stasiun pengamatan dapat dilihat pada Tabel 2 dan Gambar 2. Berdasarkan ketinggian tajuk, jenis pohon yang tertinggi secara berurutan adalah Ficus superba (40 meter), Casuarina cunning hamiana dan Schouteniaovata (35 m); Eugenia aquea (30); Eugenia sp., Tamarindus indica, Lagerstroemiaspeciosa, Syzygiumcumini, Protiumjavanicum dan Mangifera indica (25 m); Alstoniascholaris, Leucaena glauca, Ficus septica $(20 \mathrm{~m})$. Vegetasi yang lain tingginya antara 5 meter sampai dengan 15 meter. Selengkapnya pada Tabel 1.

Satwa memilih habitat yang tersedia dan sesuai untuk mempertahankan kelangsungan hidupnya. Sedangkan struktur vegetasi merupakan susunan vertikal dan distribusi spasial tumbuh- tumbuhan (vegetasi) dalam suatu komunitas. Menurut Mueller, Dombois dan Ellenberg (1974), struktur vegetasi berfungsi sebagai pengaturan ruang hidup suatu individu dengan unsur utama adalah bentuk pertumbuhan, stratifikasi dan penutupan tajuk.

Hasil análisis Indeks keanekaragaman jenis vegetasi $(\mathrm{H})$ menurut Shannon -Wienner diperoleh sebesar antara 1,33 di pinggir hutan pelataran candi dan 1,45. di dalam hutan. Rendahnya nilai indeks keanekaragaman jenis pada stasiun I karena areal tersebut merupakan pelataran candi yang vegetasi pohonnya banyak yang ditebang untuk keperluan estetik. Adapun areal dalam hutan selain merupakan hutan tanaman juga masih merupakan hutan alami. Berikut disajikan dalam bentuk diagram hasil análisis keanekaragaman jenis $(\mathrm{H})$ di areal wisata Gunung Pengsong Kabupaten Lombok Barat pada Bulan Agustus Tahun 2020. 


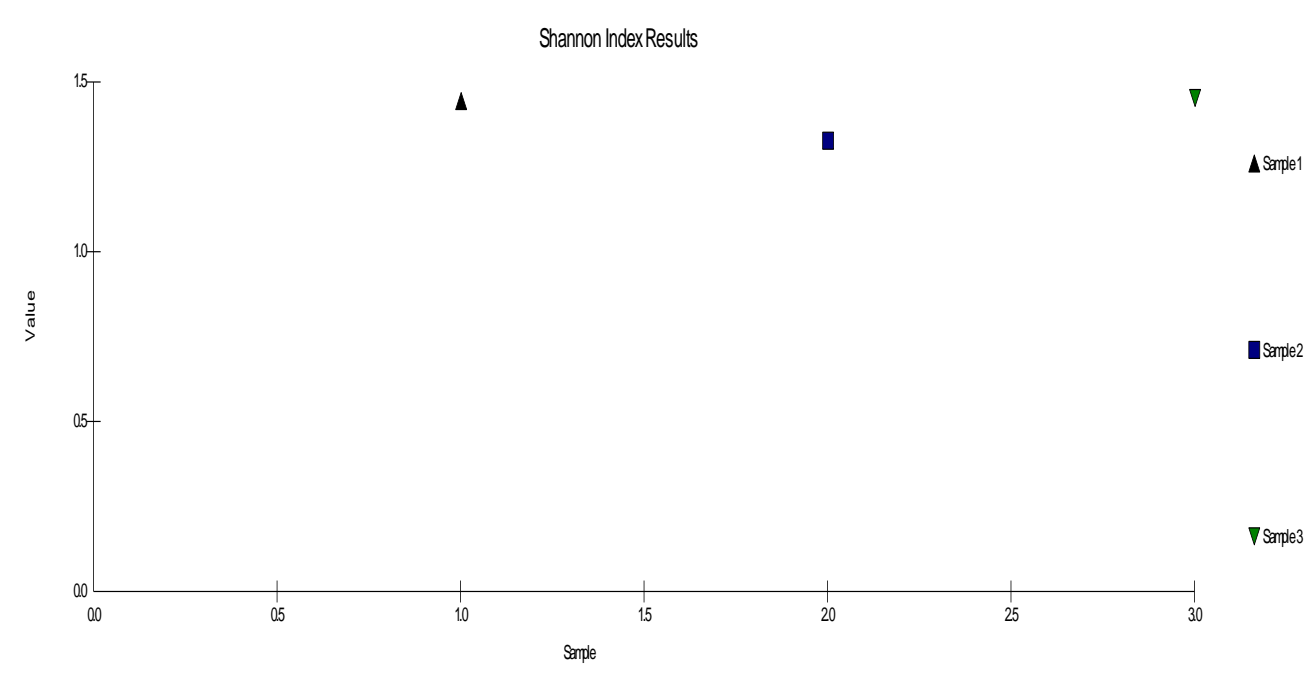

Gambar 1. Hasil Analisis Indeks Keanekaragaman Jenis (H) Vegetasi areal wisata Gunung Pengsong Kabupaten Lombok Barat Bulan Agustus Tahun 2020

Nilai Indeks keanekaragaman jenis vegetasi sebesar 1,33 sampai 1,45 pada masingmasing stasiun di areal wisata Gunung Pengsong Kabupaten Lombok Barat bila dibandingkan dengan nilai indeks keanekaragaman jenis (Hmaks) pada masing-masing stasiun pengamatan yang berkisar antara 1,45 sampai 1,54 . Indeks keanekaragaman gabungan kedua stasiun diperoleh sebesar 1,46 dengan H-maks sebesar 1,69 (Tabel 2) digolongkan tinggi. Hal itu berarti cukup memberikan kemantapan pada

Species Distribution ekosistem bila terjadi gangguan, misalnya, bila ada salah satu jenis vegetasi yang berperan dalam siklus materi atau aliran energy hilang, proses ekologis di areal tersebut tetap berjalan karena ada alternative jenis tumbuhan lain yang mengganti perannya tersebut.

Berikut disajikan dalam bentuk diagram hasil analisis pola sebaran dan kesamaan jenis vegetasi antar lokasi di areal wisata Gunung Pengsong Kabupaten Lombok Barat pada Bulan Agustus Tahun 2020.

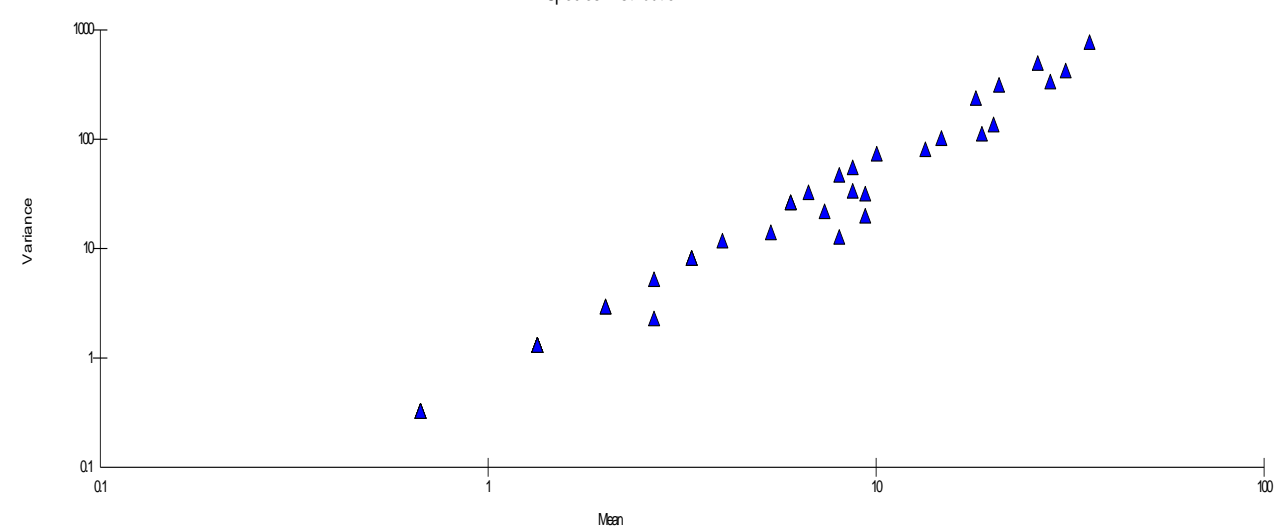

Gambar 2. Pola Distribusi Jenis Vegetasi di areal Wisata Gunung Pengsong Kabupaten Lombok Barat pada Bulan Agustus Tahun 2020.

Tabel 3. Hasil Analisis Indeks Kesamaan Jenis Vegetasi antar stasiun pengamatan di Gunung Pengsong Bulan Agustus Tahun 2020

\begin{tabular}{|l|l|l|l|} 
Similarity Matrix & Sample 1 & Sample 2 & Sample 3 \\
Sample 1 & $*$ & 20.1802 & 32.3263 \\
Sample 2 & $*$ & $*$ & 89.332 \\
Sample 3 & $*$ & $*$ & $*$ \\
\hline
\end{tabular}




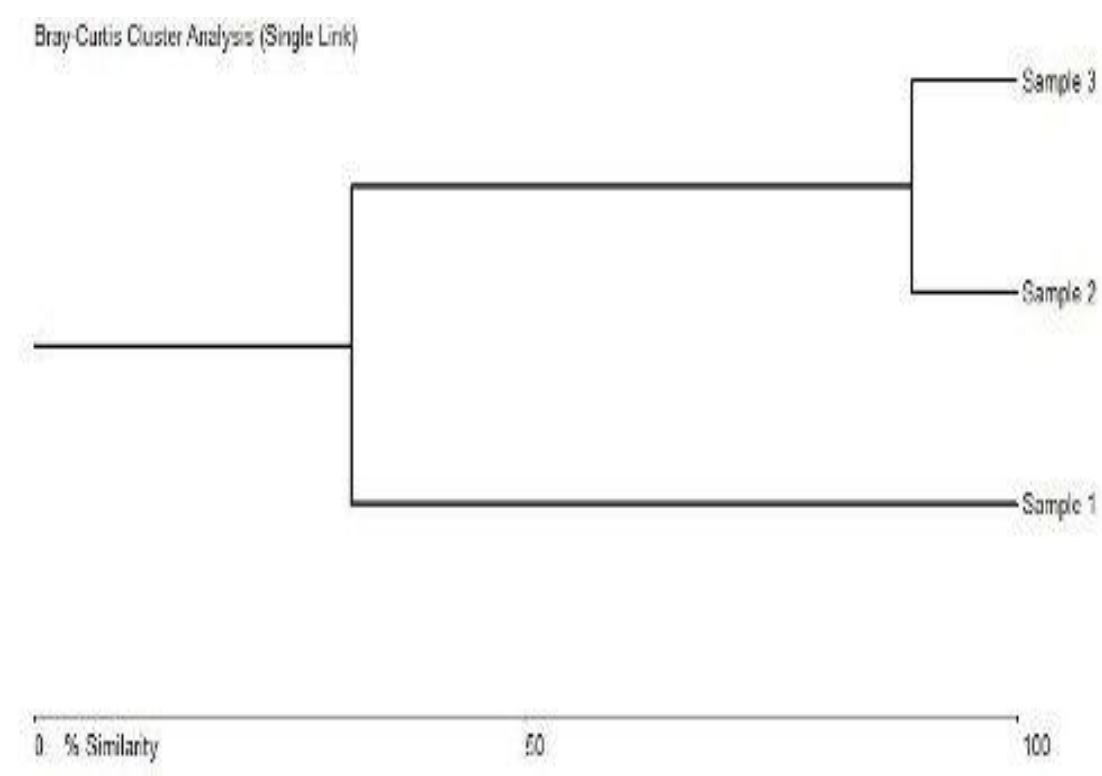

Gambar 3. Dendogram Kesamaan jenis vegetasi antar stasiun pengamatan di areal wisata Gunung Pengsong Bulan Agustus Tahun 2020.

Hasil perhitungan Indeks Kesamaan jenis (IS) (Tabel 3 dan gambar 3) vegetasi antara stasiun II dengan III yaitu sebesar 0,89 yang berarti bahwa komunitas vegetasinya relatif sama. Hal ini karena stasiun II dengan III keduanya terletak di dalam areal hutan, vegetasinya masih alami. Adapun stasiun I dengan II dan I dengan III Indeks Kesamaan jenis (IS) Indeks Kesamaan jenisnya (IS) tercatat 0,21 dan 0,32 artinya komunitas vegetsinya berbeda. Kondisi ini karena areal stasiun I vegetasi alaminya sudah banyak ditebang dan diganti dengan vegetasi yang bernilai estetik dan sebagai sumber pakan satwa (Tabel4-6).

Dari data keberadaan dan analisis keanekaragaman jenis (H), Distribusi (D) dan Kesamaan jenis (IS) antara lokasi diperoleh cukup memberikan kemantapan pada ekosistem bila terjadi gangguan, misalnya, bila ada salah satu jenis vegetasi yang berperan dalam siklus materi atau aliran energi hilang, proses ekologis di habitat tersebut tetap berjalan karena ada alternatif jenis tumbuhan lain yang mengganti perannya tersebut.

\section{Makanan Macaca fascicularis di Kawasan Gunung Pengsong}

Total populasi monyet di daerah wisata Gunung Pengsong kira-kira 90 ekor. $60 \%$ dari populasi tersebut berupa monyet usia muda. Habitat monyet Gunung Pengsong didominasi tumbuhan lamtaro (Leucema $s p$ ) di bagian tengah dan kebanyakan jenis tumbuhan dibagian atas tidak dimakan oleh monyet. Sebaliknya dibagian bawah didominasi oleh tumbuhan yang merupakan makanannya seperti beringin. Selain itu lokasi Gunung Pengsong dikelilingi oleh daerah pertanian dan permukiman dimana terdapat tanaman pertanian dan perkebunan.

Diet monyet sangat dipengaruhi oleh keadaan musim, seperti halnya selama melakukan penelitian dibulan Pebruari makanan yang paling banyak dimakan diantaranya buah dan daun beringin, rumput pahit, biji lamtaro, bunga johar. Sepanjang musim penghujan makanan monyet tersedia banyak di gunung tersebut mulai dari bagian tengah sampai bawah, berupa rumput dan tumbuhan tingkat tinggi dan di bagian puncak sering tersedia makanan dari sesajen upacara agama hindu. Sebliknya pada musim kering kondisi tumbuhan di Gunung Pengsong banyak yang menggugurkan daunnya dan juga rumput menjadi kering, sehingga makanan tidak tersedia cukup, akibatnya monyet turun mencari makan di sekitar bawah gunung memakan tanaman pertanian atau buah-buahan di permukiman. Hal ini juga tergantung dari pengunjung yang berekreasi, jika banyak pengunjung yang memberi makan berupa kue kering dan lain-lain, maka monyet tidak memakan tanaman milik penduduk yang terdapat 
sekitar gunung pada hari tersebut mungkin merasa cukup.

Diet monyet hasil penelitian sangat bervariasi sangat tergantung pada jenis tumbuhan. Bagian tumbuhan yang dimakan berupa daun muda, buah, bunga atau akar. Adapun jenis tumbuhan yang dimakan pada bulan Pebruari-Maret terutama beringin, rumput pahit, lamtana camara, bugenvil dan lain-lain (tabel 4). Selain tumbuhan yang tersedia, monyet juga memakan jenis hewan kecil berupa serangga (table 4). Tanaman pertanian di daerah permukiman dimakan juga oleh monyet khususnya pada musim kering. Tanaman tersebut berupa tanaman hortikultura (table 4) kasus ini merupakan msalah bagi petani karena merugikan 
Tabel 4. Vegetasi Sumber Pakan Macaca fascicularis di Gunung Pengsong

\begin{tabular}{|c|c|c|c|c|c|c|c|}
\hline No & Nama Tumbuhan & $\begin{array}{l}\text { Bagian Yang } \\
\text { Dimakan }\end{array}$ & Hewan & $\begin{array}{l}\text { Bagian yang } \\
\text { diakan }\end{array}$ & Pemukiman & $\begin{array}{l}\text { Bagian } \\
\text { yang diakan }\end{array}$ & Pengunjung \\
\hline & 1 & 2 & 3 & 4 & 5 & 6 & 7 \\
\hline 1. & Beringin (Ficus benyamina) & $\begin{array}{l}\text { Buah dan daun } \\
\text { muda }\end{array}$ & $\begin{array}{l}\text { Nama/jenis } \\
\text { Hewan }\end{array}$ & Bagian dimakan & Padi & Biji & Kacang kering \\
\hline 2. & $\begin{array}{l}\text { Rumput pahit (Acopus } \\
\text { Compresus) }\end{array}$ & Bunga/biji & Tenggarek & Semuah tubuh & Kedelai & Biji & Pisang \\
\hline 3. & Lamtana camara & Buah & Telur semut & Semua bagian & Singkong & Ubi & Biskuit \\
\hline 4. & Lamtaro (Leucema sp) & $\begin{array}{l}\text { Biji dan daun } \\
\text { muda }\end{array}$ & Telur reptil & $\begin{array}{l}\text { Kuning dan } \\
\text { putih telur }\end{array}$ & Ubi jalar & Ubi & Roti \\
\hline 5. & Ketimusa & Daun muda & Telur ayam & $\begin{array}{l}\text { Kuning dan } \\
\text { putih telur }\end{array}$ & Mentimun & Buah & Kerupuk \\
\hline 6. & Ketepu & Daun muda & Serangga daun & Semua bagian & Jagung & Biji & Kelapa muda \\
\hline 7. & Tolak/Rimge & Biji & & & Jambu air & Buah & Tebu \\
\hline 8. & Bugenvil (Bougainvillae sp) & $\begin{array}{l}\text { Daging buah dan } \\
\text { bunga }\end{array}$ & & & Nangka & Buah & $\begin{array}{l}\text { Jenis-jenis kue } \\
\text { kering }\end{array}$ \\
\hline 9. & Ketapang & Bunga & & & $\begin{array}{l}\text { Bawang } \\
\text { merah }\end{array}$ & Ubi & $\begin{array}{l}\text { Buah, beras, nasi } \\
\text { (Sesajen Upacara } \\
\text { Keagamaan) }\end{array}$ \\
\hline 10. & Rumput teki (Killinga $s p$ ) & Ubi/akar & & & Tembakau & Bunga & \\
\hline 11. & Johar (Cassia siamea Link) & Bunga & & & & & \\
\hline 12. & Ceplikan & Biji & & & & & \\
\hline 13. & Asam (Tamarandus indica 1.) & Buah muda & & & & & \\
\hline 14. & Babieu & Daun & & & & & \\
\hline 15. & Randu (Cuba petandra) & Buah muda & & & & & \\
\hline 16. & Pisang (Cubapetandradae) & Buah (mentah) & & & & & \\
\hline 17. & Kelapa (Cocus nicifera) & Buah & & & & & \\
\hline 18. & Mangga (Magnifer indica) & Buah muda & & & & & \\
\hline 19. & Kenaanga (Canangin odoratum) & Buah & & & & & \\
\hline 20. & Lamtana sp & Bunga & & & & & \\
\hline 21. & Rumput pahit sp (Axopus, s.p.) & Daun muda & & & & & \\
\hline 22. & Jenis jamur paying & Semua bagian & & & & & \\
\hline 23. & Duet Eugenia cummi & Buah & & & & & \\
\hline 24. & & & & & & & \\
\hline
\end{tabular}


Makanan yang bias diberikan pengunjung berupa: biscuit, roti, pisang, kue-kue kering, kacang- kacangan dan lain-lain (table 4). Namun pemberian makan dari pengunjung jumlahnya tidak sama setiap hari, biasanya hari libur atau minggu lebih banyak pengunjung sehingga lebih banyak makanan yang diberikan. Tetapi pemberian makan tidak merata hanya monyet yang lebih besar, kuat dan jinak akan lebih banyak mendapat makananan.

Makanan monyet berupa tumbuhan sebanyak 33 jenis dengan bagian yang dimakan sangat tergantung dari jenis tumbuhannya. Ketersediaan makanan tersebut sangat tergantung pada musim dan masa berbuah/berbunga dari tanaman. Sehingga tidak semua makanan tersebut tersedia setiap saat. Dengan demikian ada saatnya makanan berlimpah pada musim hujan dan kurang pada musim kering, selain itu tergantung dari kedatangan pengunjung. Tanaman yang menjadi sumber makanan mendominasi vegetasi bagian bawah gunung. Makanan yang paling banyak dimakan saat dilakukan penelitian adalah beringin, rumput pahit saliara dan loka, makanan tersebut banyak mengandung protein lemak dan karbohidrat. Jenis tanaman tersebut sama dengan yang di konsumsi di daerah wisata Pusuk (Setiadi \& Bachri, 1998; Setiadi \& Yamin, 2006) dan daerah Sulawesi (Supriatnaet al., 1986).

Makanan berupa hewan lebih berupa serangga kecil disebabkan daerah jelajahnya di jauh dari pantai, populasi monyet yang dekat pantai disamping memakan serangga juga memakan hewan-hewan laut. Makan berupa hewan merupakan sumber makanan yang baik sebagai sumber protein yang sangaty diperlukan oleh tubuh hewan. Sumber makanan berupa tanaman pertanian ini terjadi saat sumber makanan tumbuhan di bagian bawah tidak mencukupi, sehingga monyet memperluas daerah jelajah untuk mendapatkan makanan. Keadaan ini biasanya terjadi pada saat musim kering disebabkan banyak tanaman mengalami gugur daun. Keadaan poppulasi yang tak terkontrol ini menyebabkan kerugian petani yang cukup banyak karena tanaman dirusak sehingga tidak bisa dipanen.
Upaya pelestarian populasi secara keseluruhan perlu disesuaikan dengan daya dukung sumber makanan terendah pada saat musim kemarau. Jika populasi tidak dikendalikan bisa menyebabkan kelaparan, sehingga akan menyebabkan banyak monyet mati yang akan mengancam keberadaan populasi karena serangan penyebaran penyakit. Selain itu jika populasi tidak dikontrol, akan mengancan tanaman pertanian yang akan merugikan para petani disekitar daerah wisata. Upaya pelestarian jangka panjang perlu dilakukan penanaman atau regenerasi tanaman yang dijadikan sumber makanan, sehingga sumber makanan akan selalu tersedia. Pembatasan jumlah populasi juga merupakan pertimbangan yang sangat penting dengan cara ditangkap untuk dipindahkan atau dimanfaatkan untuk tujuan tertentu.

Melihat kenyataan pengelolaan dan pemanfaatan populasi monyet sebagai daya tarik untuk wisatawa belum tampak. Salah satu upaya yang perlu diperhatikan dalam upaya membuat daya tarik khusus untuk wisatawan, maka perlu memberdayakan populasi monyet dengan cara domestikasi atau membuat akrab dengan pengunjung dan jika memungkinkan dapat membuat monyet mengerti perintah pengelola atau orang tertentu yang sudah dikenal untuk melakukan atraksi atau kegiatan tertentu, sehingga akan lebih menarik banyak wisatawan atau pengunjung baik lokal, nasional atau internasional.

\section{Perilaku Macacca fascicularis di Areal Wisata Gunung Pengsong}

Hasil penjelajahan dan sensus yang dilakukan terhadap populasi Macaca fascicularis selama enam hari pada areal seluas sekitar 15 hektar di kawasan wisata Gunung Pengsong, tercatat sebanyak 83 ekor 83 ekor terdiri dari 9 ekor $( \pm 11 \%)$ jantan dewasa, 29 ekor $( \pm 35 \%)$ betina dewasa dan 45 ekor $( \pm 54 \%)$ remaja dan anak. Berikut disajikan data aktivitas Macaca fascicularis selama enam hari di kawasan wisata Gunung Pengsong (Tabel 5-6). 
Tabel 5. Aktivitas Macaca fascicularis di Gunung Pengsong Tahun 2020

\begin{tabular}{|c|c|c|c|c|c|c|}
\hline \multirow[t]{4}{*}{ Aktivitas } & \multicolumn{6}{|c|}{ Frekuensi/status } \\
\hline & \multicolumn{4}{|c|}{ Induk } & \multirow{2}{*}{\multicolumn{2}{|c|}{ Remaja/anak }} \\
\hline & \multicolumn{2}{|c|}{ Jantan } & \multicolumn{2}{|c|}{ Betina } & & \\
\hline & 1 & 2 & 3 & 4 & 5 & 6 \\
\hline Makan & 14 & 16 & 20 & 18 & 12 & 13 \\
\hline Bergerak & 50 & 56 & 40 & 45 & 65 & 67 \\
\hline Kawin & 3 & 5 & 1 & 0 & 0 & 0 \\
\hline Grooming & 23 & 24 & 36 & 43 & 14 & 12 \\
\hline Mengasuh anak & 0 & 0 & 8 & 10 & 0 & 0 \\
\hline Bermain & 6 & 8 & 11 & 15 & 22 & 25 \\
\hline Tidur & 0 & 1 & 3 & 2 & 0 & 15 \\
\hline Bersuara & 4 & 3 & 7 & 7 & 12 & 11 \\
\hline \multirow[t]{2}{*}{ Agresif } & 8 & 9 & 7 & 6 & 5 & 3 \\
\hline & 109 & 124 & 136 & 150 & 135 & 152 \\
\hline Rata-rata & \multicolumn{2}{|c|}{117} & \multicolumn{2}{|c|}{143} & \multicolumn{2}{|c|}{144} \\
\hline
\end{tabular}

Tabel 6. Rata-rata Aktivitas Macaca fascicularis di Gunung Pengsong

\begin{tabular}{|c|c|c|c|}
\hline \multirow[t]{3}{*}{ Aktivitas } & \multicolumn{3}{|c|}{ Frekuensi/status } \\
\hline & \multicolumn{2}{|c|}{ Induk } & \multirow[t]{2}{*}{ Remaja/anak } \\
\hline & Jantan & Betina & \\
\hline Makan & 15 & 19 & 13 \\
\hline Bergerak & 53 & 43 & 66 \\
\hline Kawin & 4 & 1 & 0 \\
\hline Grooming & 24 & 40 & 13 \\
\hline Mengasuh anak & 0 & 9 & 0 \\
\hline Bermain & 7 & 13 & 24 \\
\hline Tidur & 1 & 3 & 8 \\
\hline Bersuara & 4 & 7 & 12 \\
\hline Agresif & 9 & 7 & 4 \\
\hline Total & 117 & 142 & 140 \\
\hline
\end{tabular}

\section{Kesimpulan}

Monyet banyak mengkonsumsi 33 jenis tumbuhan, 4 jenis serangga dan sangat tergantung pada ketersediaan makanan di lingkungannya, makanan yang diberikan pengunjung disukai monyet dan memberi nilai gizi yang baik. Populasi monyet sangat perlu dikontrol agar sesuai dengan daya dukung lingkungannya dan menghindari rusaknya tanaman pertanian disekitar area wisata.

\section{UcapanTerima Kasih}

Kami menyampaikanTerima Kasih kepada P2SLPT yang telah memberikan dana penelitian,
Lemlit UNRAM atas segala bantuannya dan Mahasiswa Biologi yang telah membantu di Lapangan.

\section{Referensi}

Aurelia, M., Kosmaryandi, N., \& Amanah, S. (2020). Potensi Ekowisata Berbasis Masyarakat Kampung Urug, Sukajaya, Bogor. Media Konservasi, 25(1), 1-9.

Awalia, H. (2017). Komodifikasi Pariwisata Halal NTB dalam Promosi Destinasi Wisata Islami di Indonesia. Jurnal Studi Komunikasi, 1(1), 19-30. 
Bambang Supriadi, S. E., \& Roedjinandari, N. (2017). Perencanaan dan Pengembangan Destinasi Pariwisata. Universitas Negeri Malang.

Daniar, M. S. (2016). Potensi Alam dan Kepariwisataan Kepulauan Karimunjawa Jepara Provinsi Jawa Tengah sebagai Medan Pengembangan Olahraga Rekreasi (Doctoral dissertation, UNS (Sebelas Maret University).

Departemen Kehutanan, BKSA. (2008). Hasil survei permasalahan gangguan kawasan konservasi Taman NasionalLore Lindu. Departemen Kehutanan, Kantor Wilayah Propinsi Sualwesi Tengah.

Departemen Kehutanan, Sub BKSA. (1995). Hasil survei permasalahan gangguan kawasan konservasi Taman Buru Pulau Moyo.Sub BKSDA Departemen Kehutanan, Kantor Wilayah Propinsi Nusa Tenggara Barat.

Direktorat Jenderal Kehutanan, Direktorat Perlindungan dan Pengawetan Alam, (1988). Desain Pengelolaan dan Pengembangan Suaka Margasatwa Bali Barat. Laporan Penelitian Fakultas Kehutanan IPB Kerjasama dengan Direktorat Perlindungan dan Pengawetan Alam Departemen Kehutanan.

Febriyanti, D. Y., \& Kiroh, H. J. (2019). Kajian Kualitas Habitat dan Tingkat Kepadatan Monyet Hitam Sulawesi (Macaca nigra) Di Kesatuan Pengelolaan Hutan Konservasi (Kphk) Tangkoko Sulawesi Utara. AgriSosioekonomi, 15(1), 65-70.

Graf, A. B. (1992). Hortica. A color cyclopedia of garden flora in all climates and indoor plants. First edition. Roehrs Company, U.S.A.

Haris, M., Soekmadi, R., \& Arifin, H. S. (2017). Potensi daya tarik ekowisata suaka margasatwa bukit Batu kabupaten bengkalis provinsi riau. Jurnal Penelitian Sosial dan Ekonomi Kehutanan, 14(1), 39-56.
Krebs CJ. (1978). EcologyThe Experimental Analysis of Distribution and Ambundance.New York: Harper and Row Publication.

Magurran, A. E. (1988). Ecologycal Diversity and Its Measurement. Chapman \& Hall, London.

Mangunjaya, F. (2015). Mempertahankan Keseimbangan: Perubahan Iklim, Keanekaragaman Hayati, Pembangunan Berkelanjutan, dan Etika Agama. Yayasan Pustaka Obor Indonesia.

Mardalis, A., \& Wijaya, R. P. (2016). Pengelolaan Daya Tarik Wisata Alam Berdasarkan Kepuasan dan Keinginan Wisatawan.

Maryadi (1993). Fauna sebagai daya tarik wisatawan dan sumber devisa. Makalah dalam lokakarya teknologi konservasi fauna. Direktorat Teknologi Pemukiman dan Lingkungan Hidup, BPP Teknologi, Jakarta.

Muller-Dombois, D. \& H. Ellenberg (1974). Aims and methods of vegetation ecology. John Wiley \& Sons, New York.

Odum, E. P. (1971). Fundamentals of ecology. W. B.Saunders, Philadelphia, Pennsylvania, USA.

Purnomo, H., Sulistyantara, B., \& Gunawan, A. (2013). Peluang usaha ekowisata di kawasan cagar alam Pulau Sempu, Jawa Timur. Jurnal penelitian sosial dan ekonomi kehutanan, 10(4), 247-263.

Santosa, Y., Siregar, J. P., Rinaldi, D., \& Rahman, D. A. (2012). Faktor-Faktor Penentu Keberhasilan Pelepasliaran Orangutan Sumatera (Pongo Abelii) di Taman Nasional Bukit Tigapuluh. Jurnal Ilmu Pertanian Indonesia, 17(3), 186-191.

Setiadi, D \& M. Yamin (2006). Diet Monyet (MacacaSp) di Daerah Wisata Pengsong: Strategi Dasar Pengembangan Ekowisata dan Konservasi. Laporan Penelitian BOPTN Universitas Mataram (Belum dipublikasi). 
Setiadi, D. \& Bachri, S. (1998) Analisa Diet Monyet (Macacasp) di Daerah Wisata Pusuk dan Kuta Lombok. Oryza. IV.15:59-66.

Supriatna, J. (2018). Konservasi Biodiversitas: Teori dan Praktik di Indonesia. Yayasan Pustaka Obor Indonesia.

Syah, F. (2017). Strategi Mengembangkan Desa Wisata. Proceeding SENDI_U. Retrieved from

https://www.unisbank.ac.id/ojs/index.php/s endi_u/article/view/5048

Utama, I. G. B. R. (2017). Pemasaran Pariwisata. Penerbit Andi. https://books.google.co.id/books hal. 37.
Winarti, I. (2011). Habitat, Populasi, Dan Sebaran Kukang Jawa (Nycticebus Javanicus Geoffroy 1812) Di Talun Tasikmalaya dan Ciamis.

https://www.researchgate.net/profile/Indah_ Winarti/publication/225280125.

Yuniarti, E., Soekmadi, R., Arifin, H. S., \& Noorachmat, B. P. (2018). Analisis Potensi Ekowisata Heart of Borneo Di Taman Nasional Betung Kerihun Dan Danau Sentarum Kabupaten Kapuas Hulu. Journal of Natural Resources and Environmental Management, 8(1), 44-54. 